\title{
Peran ecolabel awareness dan green perceived quality pada purchase intention
}

\author{
Dian Novita* \\ Universitas Teknokrat Indonesia, Bandar Lampung, Indonesia \\ diannovita@teknokrat.ac.id \\ Nurul Husna \\ Universitas Teknokrat Indonesia, Bandar Lampung, Indonesia \\ nurulhusna@teknokrat.ac.id \\ *Penulis Korespondensi
}

Submitted: Sept 02, 2020; Reviewed: Sept 08, 2020; Accepted: Nov 10, 2020

\begin{abstract}
Global market recently tend to be concerning about green market with green product. The purpose of this paper is to analyze the impact of ecolabel awareness and green perceived quality on purchase intention. This research used probability sampling technique method with random sampling procedure but based on gender (female respondent), to represent all respondent that used green cosmetic product in Bandar Lampung. It was designed from three variabels using a Likert scale. It used SmartPLS 3.0 to analyze data. The finding of this study reveals that ecolabel awareness has positive but no significant direct effect on purchase intention, whereas green perceived quality has a positive and significant effect on purchase intention.
\end{abstract}

Keywords: ecolabel awareness; green perceived quality; purchase intention

Abstrak: Kecenderungan pasar global saat ini mengarah pada produk ramah lingkungan, begitu juga dengan tren industri kosmetik di Indonesia. Tujuan penelitian ini adalah untuk menganalisis peran ecolabel awareness dan green perceived quality pada purchase intention. Penelitian ini menggunakan metode probability sampling dengan random sampling procedure, dengan sampel berdasarkan jenis kelamin (wanita) untuk mewakili seluruh responden pengguna kosmetik ramah lingkungan di Bandar Lampung. Kuesioner penelitian disusun berdasarkan tiga variabel dengan menggunakan skala likert. Penelitian menggunakan bantuan software SmartPLS 3.0 untuk menganalisa data. Temuan dalam penelitian ini adalah bahwa ecolabel awareness tidak memiliki pengaruh yang positif dan signifikan terhadap minat beli konsumen, sedangkan green perceived quality memiliki pengaruh yang positif dan signifikan terhadap niat beli.

Kata kunci: ecolabel awareness; green perceived quality; purchase intention

\section{PENDAHULUAN}

Tren pasar global saat ini mengarah pada produk ramah lingkungan. Tidak terkecuali pada produk kosmetik, perkembangan bisnis produk kosmetik beberapa tahun ini sangat pesat sekali di Indonesia. Seiring dengan perkembangan teknologi, khususnya media sosial yang membuat siapa saja terutama 
kaum milenial dapat dengan mudahnya mendapatkan kemampuan merias wajah layaknya profesional ataupun sebaliknya mereka juga dapat menjadi influencer dalam dunia kecantikan. Hal ini merupakan faktor pendukung pesatnya industri kosmetik belakangan ini di Indonesia secara umumnya dan di Bandar Lampung secara khususnya. Para pelaku bisnis harus tanggap terhadap terhadap hal tersebut, dengan memertimbangkan perilaku konsumen saat ini, yang mana orang yang perduli akan lingkungan akan berusaha untuk melindungi lingkungannya (Fraj \& Martinez, 2006) dalam bertindak, karena hal ini dapat menjadi peluang atau justru keterpurukan bagi pelaku bisnis kosmetik yang gagal menangkap peluang tersebut. Pesatnya industri bisnis, salah satunya ditandai dengan masuknya berbagai merek dari luar negeri baik dari negara-negara barat maupun timur, yang belum tentu semua merek tersebut aman digunakan. Ecolabel adalah salah satu bentuk komunikasi langsung produsen kepada konsumen untuk menginformasikan kepada konsumen bahwa produk tersebut aman dikonsumsi, baik bagi tubuh manusia maupun lingkungan, jika dibandingkan dengan produk sejenis yang tidak memiliki label ecolabel (Waluyo, 2016).

Tabel 1 Perkembangan pasar industri kosmetik di Indonesia

\begin{tabular}{ccc}
\hline Tahun & Market $($ milyar Rp) & Kenaikan $(\%)$ \\
\hline 2010 & 8.900 & - \\
2011 & 8.500 & $(4,49)$ \\
2012 & 9.760 & 14,82 \\
2013 & 11.200 & 14,75 \\
2014 & 12.874 & 14,95 \\
$\left.2015^{*}\right)$ & 13.943 & 8,30 \\
Kenaikan rerata, \% tahun & 9,67 \\
\hline
\end{tabular}

*) angka sementara

Sumber: Reference analysis of business in Indonesia (2016)

Rumusan masalah pada penelitian ini adalah bagaimana peran ecolabel awareness dan green perceived quality pada niat pembelian (purchase intention)? Adapun tujuan dari penelitian ini adalah untuk mengkaji dan menganalisis peranan ecolabel awareness dan green perceived quality pada niat pembelian (purchase intention). Penelitian pada ecolabel sebelumnya pernah dilakukan, antara lain penelitian yang bertujuan meneliti dampak atribut (green marketing tools) pada perilaku pembelian konsumen, yang mana hasilnya terdapat kecenderungan konsumen untuk membeli produk ber-ecolabel (Rahbar \& Wahid, 2011).

Penelitian selanjutnya mengenai pengaruh ecolabel pada niat pembelian produk Body Shop, yang mana hasilnya dari sepuluh hipotesis yang diajukan, enam hipotesis terdukung dan empat hipotesis lainnya tidak terdukung. Penelitian lainnya menemukan bahwa pemberian informasi secara pribadi melalui tanda ecolabel pada produk mendorong niat pembelian konsumen (Riyanto, Soesanto, \& Sihombing, 2018). Yang (2017) meneliti perilaku konsumen terhadap produk ramah lingkungan. Selain itu, melalui penelitian pada dua tipe produk ber-ecolabel yaitu produk milik pribadi dan pemerintah, ditemukan bahwa konsumen lebih merespon ecolabel pada produk pribadi dibandingkan pada produk pemerintah (Hwang, Park, \& Kim, 2016). Penelitian Doszhanov \& Ahmad (2015) menemukan bahwa green brand awareness, green brand trust, dan green perceived quality berpengaruh signifikan pada niat beli konsumen. Pengetahuan seseorang akan produk ramah lingkungan akan mendorong orang tersebut untuk membeli produk ramah lingkungan (Rini, Sukaatmadja, \& Giantari, 2017).

Ada beberapa penelitian mengenai perilaku konsumen terhadap ecolabel ataupun green marketing, namun belum ada penelitian yang berfokus pada keterkaitan dua variabel green marketing, yaitu ecolabel dan green perceived quality pada purchase intention terhadap produk berwawasan lingkungan (green product), khususnya di Bandar Lampung. Ecolabel awareness didefinisikan sebagai alat yang memfasilitasi konsumen dalam pengambilan keputusan, khususnya saat memilih produk ramah lingkungan (Riyanto dkk., 2018). Ecolabel bertujuan meyakinkan konsumen atau calon pembeli bahwa produk tersebut ramah lingkungan. 
H1: Kesadaran pada ekolabel (ecolabel awareness) secara langsung berpengaruh signifikan pada purchase intention.

Green perceived quality adalah proses menerjemahkan, memilih informasi yang berguna dalam menciptakan gambaran yang berarti (Kotler \& Keller, 2009), penilaian konsumen pada keunggulan suatu produk yang ramah lingkungan (Chen \& Chang, 2013). Menurut peneliti sendiri, green perceived quality dapat diartikan sebagai penilaian konsumen mengenai kualitas sebuah produk yang ramah lingkungan.

H2: Green perceived quality secara langsung berpengaruh signifikan pada niat beli (purchase intention).

\section{METODE}

Penelitian ini merupakan penelitian kuantitatif. Populasi pada penelitian ini adalah konsumen kosmetik di Bandar Lampung dengan jumlah sampel penelitian 100 orang responden. Hal ini sesuai dengan pendapat para ahli (Sugiyono, 2017) bahwa ukuran sampel yang layak dalam penelitian adalah 30 orang sampai dengan 500 orang responden. Berdasarkan kriteria tersebut, maka jumlah penelitian tersebut dapat dikatakan telah memenuhi syarat. Teknik pengambilan sampel yang digunakan adalah probability sampling yang mana setiap responden memiliki kesempatan yang sama untuk menjadi sampel (Sugiyono, 2017) dan prosedur random sampling, yang mana responden diambil secara acak dari para konsumen kosmetik di Bandar lampung. Penelitian ini menggunakan tiga buah variabel, yaitu ecolabel awareness, green perceived quality, dan niat beli (purchase intention).

Tabel 2 Definisi operasional variabel

\begin{tabular}{|c|c|c|c|}
\hline Variabel & & Variabel teramati & Skala \\
\hline \multirow[t]{4}{*}{$\begin{array}{l}\text { Ecolabel } \\
\text { awareness }\end{array}$} & EA1 & $\begin{array}{l}\text { Mengetahui bahwa ecolabel terdapat pada produk ramah } \\
\text { lingkungan (Devi, Pudaruth, \& Noyaux, 2012) }\end{array}$ & Ordinal \\
\hline & EA2 & $\begin{array}{l}\text { Menyadari keberadaan ecolabel pada saat berbelanja (Nguyen \& } \\
\text { Du, 2010) }\end{array}$ & Ordinal \\
\hline & EA3 & $\begin{array}{l}\text { Menyadari bahwa Pemerintah Indonesia mendukung ecolabel } \\
\text { (Nguyen \& Du, 2010) }\end{array}$ & Ordinal \\
\hline & EA4 & $\begin{array}{l}\text { Mengetahui bahwa ecolabel adalah perangkat kebijakan yang } \\
\text { bertujuan untuk membimbing konsumen pada konsumsi } \\
\text { berkelanjutan (Nguyen \& Du, 2010) }\end{array}$ & Ordinal \\
\hline \multirow{3}{*}{$\begin{array}{l}\text { Green } \\
\text { perceived } \\
\text { quality }\end{array}$} & GPQ1 & $\begin{array}{l}\text { Menganggap bahwa produk ecolabel itu bermutu baik (Chen \& } \\
\text { Chang, 2013) }\end{array}$ & Ordinal \\
\hline & GPQ2 & $\begin{array}{l}\text { Menganggap bahwa product ecolabel itu aman dikonsumsi (Chen \& } \\
\text { Chang, 2013) }\end{array}$ & Ordinal \\
\hline & GPQ3 & $\begin{array}{l}\text { Menganggap bahwa produk ecolabel itu aman bagi lingkungan } \\
\text { (Chen \& Chang, 2013) }\end{array}$ & Ordinal \\
\hline \multirow[t]{2}{*}{$\begin{array}{l}\text { Purchase } \\
\text { intention }\end{array}$} & PI1 & $\begin{array}{l}\text { Peduli terhadap penggunaan ecolabel pada produk ramah } \\
\text { lingkungan (Lefébure \& Muñoz, 2011) }\end{array}$ & Ordinal \\
\hline & PI2 & $\begin{array}{l}\text { Ecolabel dapat meyakinkan pembeli untuk membeli produk ramah } \\
\text { lingkungan (Nguyen \& Du, 2010) }\end{array}$ & Ordinal \\
\hline
\end{tabular}

Sumber: Direplikasi dan dimodifikasi dari Muslim \& Indriani (2014)

Penelitian ini menggunakan software SmartPLS 3.0 dalam menganalisis data. Pengujian validitas dan reliabilitas diukur dari nilai average variance expected (AVE) minimal sebesar 0,5 yang mana hal ini menunjukkan ukuran validitas yang baik, sedangkan reliabilitas diukur melalui cronbach's alpha, minimal sebesar 0,7 sebagai standar ukuran reliabilitas yang baik. 


\section{HASIL DAN PEMBAHASAN}

Hasil average variance expected (AVE) pada penelitian ini lebih dari 0,5 , yang mana hal ini menunjukkan convergent validity yang baik. Demikian juga dengan nilai cronbanch alpha-nya yang lebih dari 0,7 yang berarti bahwa konstruk memiliki validitas yang tinggi. Hasil uji validitas dan reliabilitas dapat dilihat pada Tabel 3 dan Tabel 4 berikut.

Tabel 3 Hasil uji reliabilitas

\begin{tabular}{lcc}
\hline \multicolumn{1}{c}{ Variabel } & Cronbach's alpha & Status \\
\hline Ecolabel awareness (X1) & 0,767 & Reliabel \\
Green perceived quality (X2) & 0,812 & Reliabel \\
Purchase intention (Y) & 0,888 & Reliabel \\
\hline Sur: Hail pen
\end{tabular}

Sumber: Hasil pengolahan SmartPLS 3.0 (2020)

Tabel 4. Hasil uji validitas

\begin{tabular}{lll}
\hline Variabel & AVE & Status \\
\hline Ecolabel awareness $(\mathrm{X} 1)$ & 0,588 & Valid \\
Green perceived quality (X2) & 0,726 & Valid \\
Purchase intention $(\mathrm{Y})$ & 0,899 & Valid \\
\hline
\end{tabular}

Sumber: Hasil pengolahan SmartPLS 3.0 (2020)

Gambar 1 menunjukkan model dari penelitian ini, yang mana menjelaskan hubungan antar variabel.

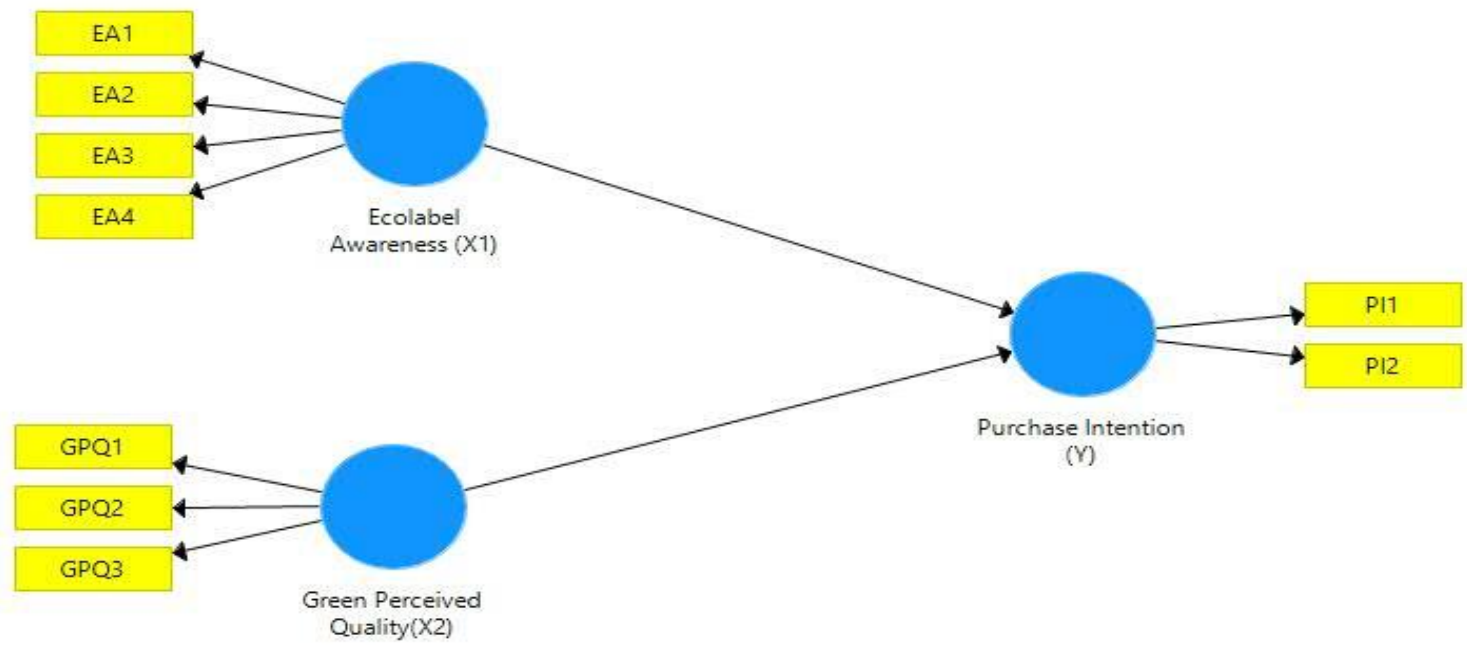

Gambar 1. Model penelitian

Sumber: Hasil olah SmartPLS 3.0 (2020)

Tabel 5 menunjukkan bahwa H1 tidak terdukung karena pengaruh ecolabel awareness pada purchase intention tidak signifikan, yang ditunjukkan oleh nilai $p$ value sebesar 0,708 atau lebih dari 0,05 yang berarti bahwa ecolabel awareness tidak berpengaruh signifikan terhadap niat beli konsumen kosmetik. Hal ini didukung oleh penelitian sebelumnya yang menyatakan bahwa kesadaran ekolabel (ecolabel awareness) dan keberadaan (ecolabel availability) hanya berpengaruh tidak langsung pada niat beli (Muslim \& Indriani, 2014), meskipun ada juga penelitian serupa di Swedia yang menyatakan bahwa keberadaan dan kesadaran konsumen akan ecolabel berpengaruh positif dan signifikan baik secara langsung maupun tidak langsung (Devi et al., 2012). Kendati demikian, hal ini sangat mungkin terjadi mengingat adanya perbedaan budaya di setiap negara. Budaya merupakan salah satu faktor yang memengaruhi perilaku konsumen (Kotler \& Keller, 2009), karena budaya merupakan landasan manusia dalam bertindak dan bertingkah laku. Dengan demikian, generalisasi untuk hal ini tidak dapat dilakukan. 
$\mathrm{H} 2$ dalam penelitian ini terdukung, karena memiliki $p$ value kurang dari $5 \%$, yaitu sebesar 0,000 , yang memiliki makna bahwa green perceived quality memiliki pengaruh signifikan terhadap purchase intention. Hal ini sesuai dengan penelitian terdahulu yang menyatakan bahwa green perceived quality memiliki hubungan positif pada purchase intention (Ankit \& Mayur, 2013; Yang, 2017).

Tabel 5. Path coefficient

\begin{tabular}{lcc}
\hline Hipotesis & T-statistic & $P$-values \\
\hline H1: Ecolabel awareness $(\mathrm{X} 1) \rightarrow$ Purchase intention $(\mathrm{Y})$ & 0,375 & 0,708 \\
$\mathrm{H} 2:$ Green perceived quality $(\mathrm{X} 2) \rightarrow$ Purchase intention $(\mathrm{Y})$ & 7,165 & 0,000 \\
\hline
\end{tabular}

Sumber: Hasil pengolahan SmartPLS 3.0 (2020)

\section{SIMPULAN DAN SARAN}

Hanya green perceived quality yang memiliki pengaruh terhadap niat beli (purchase intention), sedangkan kesadaran konsumen terhadap ecolabel pada produk ramah lingkungan masih rendah. Hal ini lah yang menyebabkan ecolabel pada penelitian ini tidak berpengaruh signifikan terhadap niat beli (purchase intention). Penelitian ini memiliki implikasi praktis bagi pemerintah maupun perusahaan dalam perdagangan global. Produk yang ber-ecolabel memiliki nilai yang lebih tinggi dibandingkan dengan yang tidak memiliki label tersebut, sehingga produk ramah lingkungan tersebut akan meningkatkan pendapatan perusahaan sekaligus pendapatan negara. Oleh karena itu, penting bagi perusahaan dan juga pemerintah untuk saling berkerjasama dalam mengedukasi konsumen akan pentingnya mengonsumsi produk ramah lingkungan karena akan berdampak positif terhadap kesehatan konsumen dan kelestarian lingkungan.

Penelitian ini tidak luput dari keterbatasan, terbatasnya responden hanya wanita dan lokasi penelitian hanya di Bandar lampung saja, membuat penelitian ini belum dapat digeneralisasi. Saran untuk penelitian selanjutnya dapat meneliti lebih jauh lagi sikap konsumen tidak hanya dari kesadaran akan ekolabel (ecolabel awareness) saja, namun dapat juga meneliti indikator sikap konsumen yang lainnya seperti pengetahuan konsumen terhadap produk ramah lingkungan (green product knowledge), kepercayaan pada produk ramah lingkungan (green brand trust), perhatian terhadap produk ramah lingkungan. Selain itu, perlu adanya perluasan cakupan produk ramah lingkungan yang lain, seperti makanan atau elektronik, yang disertai dengan lokasi penelitian yang lebih luas lagi baik di seluruh Indonesia atau pun di luar negeri, sehingga prediksi model dapat menjadi lebih tepat.

\section{ACKNOWLEDGEMENTS}

Ucapan terima kasih peneliti sampaikan kepada Kementrian Pendidikan Tinggi yang telah mendanai penelitian ini.

\section{REFERENSI}

Ankit, G., \& Mayur, R. (2013). Green marketing: Impact of green advertising on consumer purchase intention. Advances in Management, 6(9), 14-17. Diperoleh dari https://www.questia.com/library/journal/1P3-3084104991/green-marketing-impact-of-greenadvertising-on-consumer.

Chen, Y. S., \& Chang, C. H. (2013). Towards green trust: The influences of green perceived quality, green perceived risk, and green satisfaction. Management Decision, 5(1), 63-82. DOI: https://doi.org/10.1108/00251741311291319.

Devi, J. T., Pudaruth, S., \& Noyaux, M. N. E. (2012). Analysing the impact of green marketing strategies on consumer purchasing patterns in Mauritius. World Journal of Entrepreneurship, Management and Sustainable Development, 8(1), 36-59. DOI: https://doi.org/10.1108/20425961211221615.

Doszhanov, A., \& Ahmad, Z. A. (2015). Customers' intention to use green products: The impact of green brand dimensions and green perceived value. EDP Sciences, 18, 1-17. DOI: https://doi.org/10.1051/ shsconf/20151801008. 
Fraj, E., \& Martinez, E. (2006). Influence of personality on ecological consumer behaviour. Journal of Consumer Behaviour, 5(May-June), 167-181. DOI: https://doi.org/10.1002/cb.169.

Hwang, J. A., Park, Y., \& Kim, Y. (2016). Why do consumers respond to eco-labels? The case of Korea. SpringerPlus, 5(1915), 1-13. DOI: https://doi.org/10.1186/s40064-016-3550-1.

Kotler, P., \& Keller, K. L. (2009). Manajemen pemasaran, Edisi 13. Jakarta: Erlangga.

Lefébure, A., \& Muñoz, R. R. (2011). Communicating to consumers in Sweden with ecolabels - Is the message getting through? Swedia: Umeå School of Business. Diperoleh dari https://www.divaportal.org/smash/get/diva2:430238/FULLTEXT02.pdf.

Muslim, E., \& Indriani, D. R. (2014). Analisis pengaruh eco-label terhadap kesadaran konsumen untuk membeli green product. Jurnal Manajemen Teknologi, 13(1), 66-80. DOI: http://dx.doi.org/ 10.12695/jmt.2014.13.1.6.

Nguyen, L. Q., \& Du, Q. (2010). Effectiveness of eco-label? A Sudy of Swedish University student's choices on ecological food. Umea School of Business, Swedia. Diperoleh dari https://www.researchgate.net/publication/277764041.

Rahbar, E., \& Wahid, N. A. (2011). Investigation of green marketing tools' effect on consumers' purchase behavior. Business Strategy Series, 12(2), 73-83. DOI: https://doi.org/10.1108/17515631111114877.

Reference Analysis of Business in Indonesia (2016). Perkembangan pasar industri kosmetik Indonesia, 2010-2015. Diperoleh dari https://cci-indonesia.com/perkembangan-pasar-industri-kosmetik-diindonesia-2010-2015/.

Rini, A. S., Sukaatmadja, I. P. G., \& Giantari, I. G. A. K. (2017). Pengaruh pengetahuan lingkungan dan keperdulian lingkungan terhadap sikap dan niat beli produk hijau "The Body Shop" di kota Denpasar. E-Jurnal Ekonomi dan Bisnis Universitas Udayana, 6(1), 137-166. Diperoleh dari https://ojs.unud.ac.id/index.php/EEB/article/view/23972.

Riyanto, V., Soesanto, S. B., \& Sihombing, S. O. (2018). Peranan ekolabel dalam niat pembelian: Suatu studi empiris pada merek The Body Shop. Mix: Jurnal Ilmiah Manajemen, 8(3), 504-522. DOI: https://doi.org/10.22441/mix.2018.v8i3.004.

Sugiyono. (2017). Metode penelitian bisnis (Pendekatan kuantitatif, kualitatif, kombinasi, dan R\&D). Bandung: PT Alfabeta.

Waluyo, M. P. E. (2016). Mengenal perkembangan ekolabel Indonesia. HarianBernas.Com. Diperoleh dari https://www.bernas.id/16985-mengenal-perkembangan-ekolabel-indonesia.html.

Yang, Y. C. (2017). Consumer behavior towards green products. Journal of Economics, Business and Management, 5(4), 160-167. DOI: https://doi.org/10.18178/joebm.2017.5.4.505. 